\title{
Supporting Student Learning Toward Twenty-First-Century Skills Through Digital Storytelling
}

\author{
Niemi, Hannele \\ Springer Nature Singapore Pte Ltd. \\ 2019
}

Niemi , H , Niu , S J , Li , B \& Vivitsou , M 2019 , Supporting Student Learning Toward Twenty-First-Century Skills Through Digital Storytelling . in S Yu , H Niemi \& J Mason (eds), Shaping Future Schools with Digital Technology : An International Handbook. Perspectives on Rethinking and Reforming Education, Springer Nature Singapore Pte Ltd. , Singapore , pp. 95-112 . https://doi.org/10.1007/978-981-13-9439-3_6

http://hdl.handle.net/10138/333521

https://doi.org/10.1007/978-981-13-9439-3_6

acceptedVersion

Downloaded from Helda, University of Helsinki institutional repository.

This is an electronic reprint of the original article.

This reprint may differ from the original in pagination and typographic detail.

Please cite the original version. 


\section{Supporting Student Learning towards $21^{\text {st }}$ Century Skills through Digital Storytelling}

Hannele Niemi \& Jenny Niu \& BaoPing Li \& Marianna Vivitsou 



\begin{abstract}
This chapter gives an overview of Digital storytelling (DST) as a pedagogical method that support teachers' practices and students' learning to meet the needs and requirements of $21^{\text {st }}$ century skills by making student-centered knowledge creation possible at schools. Digital stories are student-generated videos that can consist of single or multiple events in curriculum-related topics or other themes for students' learning. The chapter starts with description of megatrends in learning and teaching environments and changes in working life. DST is reflected on as a method that prepares students to new knowledge ecosystem and open learning spaces. The conceptual model of Global Sharing Pedagogy is used as a structure of these reflections. The chapter also illustrates DST in three case studies: digital stories across countries, a video inquiry project in STEM learning and teaching, and learning math with DST. Based on these case studies, in the final section we discuss evaluation strategies that should be considered when moving towards student driven knowledge creation.
\end{abstract}

We conclude by making recommendations for using DST in learning and teaching. The main conclusion is that DST is an efficient pedagogical method that can be used at schools to support students' development of $21^{\text {st }}$ century skills. Additionally, this method also provides plenty of opportunities for students-centered active learning which leads to increased students' agency, engagement, learning motivation and joyful learning.

Keywords: Digital storytelling, $21^{\text {st }}$ century skills, student-centered knowledge creation, engagement, ICT used in learning 


\section{INTRODUCTION}

\section{Changing Learning and Teaching Environments}

The concept of learning has gone through a multi-layered process of redefinition in recent years. Academically, it is typically regarded as an active individual process, whereby learners construct their own knowledge base. Learning is also increasingly viewed as a process that is based on sharing and participation with different partners in a community, and as a holistic constructing process that is interconnected with learners' emotional, social, and cultural premises (Cole, 1991; Salomon, 1993; Cole \& Cigagas, 2010; Niemi, 2009; Säljö, 2012; Hakkarainen et al., 2013). The concept of "life-long learning" is more of a life-course process.

We learn in different situations and areas of life that are cross-boundary. Learning and knowledge are no longer the monopolistic domains of schools, or even universities. In our modern societies, there are many forums of learning, which may be called learning spaces. Working life and work organizations are important learning spaces (Nonaka \& Konno, 1998; Nonaka \& Takeuchi, 1995; Nonaka \& Toyama, 2003). Technology-enriched learning tools and spaces with mobile technology, social media, and all existing digital resources create a powerful arena for learning, both in formal and informal education settings.

Our learning is life-wide, and consists of vertical life-course learning, as well as horizontal dimensions. This means that there are continuous processes of learning: vertically, throughout various ages, and horizontally, in cross-boundary spaces of life (Niemi, 2003). Learning is not limited to certain ages or institutions. Learning exits in every moment and every situation if we become aware of the learning and reflect on the learning. 
These changes in the way learning takes place are the consequence of worldwide megatrends that have unleashed sweeping changes with ongoing innovations with digital technologies and communications.

\section{$.21^{\text {st }}$ Century Skills as the Aim of Educational Systems}

The way to prepare a new generation for the future, its working life, and life-wide learning has become an urgent topic on the agenda of educational systems (e.g., Binkley et al., 2012). The European Union (2006) has defined the eight core competencies for lifelong learning, and the Organization for Economic Cooperation and Development as well as many global organizations have identified necessary $21^{\text {st }}$ century skills (Griffin 2013; Griffin, McGaw, \& Care, 2013). While there is some variation, the most important message is that schools must seek new forms of teaching and learning. Many discussions and documents have proposed ways to face the future, and have delineated the roles of schools and teachers in these changing contexts (e.g., Bellanca \& Brandt, 2010; Griffin, McGaw, \& Care, 2012).

Andreas Schleicher (2012) argued that "Everyone realises that the skills that are easiest to teach and easiest to test are now also the skills that are easiest to automate, digitise and outsource. Of ever-growing importance, but so much harder to develop, are ways of thinking - creativity, critical thinking, problemsolving, decision-making and learning; ways of working - including communication and collaboration; and tools for working - including information and communications technologies".

Although definitions of $21^{\text {st }}$ century skills vary, there are some commonalities. The most important factor is that students should have:

- The capacity to learn throughout their lives, and that education should provide the skills and mental tools to enable them to do so.

- Inquiry and knowledge-creation abilities are important, but they should be connected with analytical and critical thinking skills, as well as creativity.

- Students should have the capability to ask questions, and not simply seek or repeat ready answers. They need the ability to work independently, but also, increasingly, collaboratively. Life is ever more bound up with technology; learning environments are continuously changing, and ICT provides many new learning opportunities. 
Working life is also changing dramatically. Increased global interconnectivity puts diversity and adaptability at the center of organizational operations. Workplace robotics nudges human workers out of rote, repetitive tasks, and new media ecology requires new literacies. Davies, Fidler and Gorbis (2011) summarized that skills and abilities related to higher-level thinking, and social relationships that cannot be easily transferred to machines, will enable us to create unique insights and be critical to decision-making. Workers will require social skills that enable them to collaborate and build relationships of trust locally, as well as globally. Workers must also be capable of responding to unique, unexpected circumstances that may occur at any moment (Autor, 2010). Jones, Valdez, Nowakowski, and Rasmussen (1994) suggested that successful, engaged learners are responsible for their own learning. These students are self-regulated, and are capable of defining their own learning goals, and evaluating their own achievements. They are also energized by their learning; their joy in learning leads to a lifelong passion for solving problems, understanding, and taking the next step in their thinking. These learners are strategic, in that they know how to learn and are capable of transferring knowledge to solve problems creatively. Engaged learning also involves being collaborative, that is, valuing and having the skills to work with others.

Taylor and Parsons (2011) analyzed what student engagement might be. They introduced several types of engagement: academic, cognitive, intellectual, institutional, emotional, behavioral, social, and psychological. After exploring numerous definitions, they concluded that the following criteria characterize engagement:

- Learning that is relevant, real, and intentionally interdisciplinary, at times moving learning from the classroom into the community.

- Technology-rich learning environments, not just computers, but all types of technology, including scientific equipment, multimedia resources, industrial technology, and diverse forms of portable communication technology.

- Learning environments that are positive, challenging, and open, sometimes called "transparent" learning climates, encourage risk-taking and guide learners toward co-articulated high expectations. Students are involved in assessment for, and of, learning.

- Collaboration via respectful "peer-to-peer" type relationships between students and teachers. 


\section{DIGITAL STORYTELLING AS A PEDAGOGICAL METHOD}

\section{What Is Digital Storytelling?}

According to Jenkins et al. (2009), Digital Storytelling (DST) is one mode of twenty-first century learning. As a pedagogical method, DST builds on learnercentered approaches (Kearney, 2009; Yang, 2012) and it allows teacher practices and students' learning to meet the needs and requirements of $21^{\text {st }}$ century skills. Robin (2008) proposed that DST takes advantage of the creative potential of modern communication technologies. Students are encouraged to become creators, producers and discussants, rather than simply passive audience members. DST allows students to work collaboratively in groups, plan the task at hand, implement and evaluate the stories as products. Figure 1 shows the process of conducting Digital Storytelling as pedagogical method.

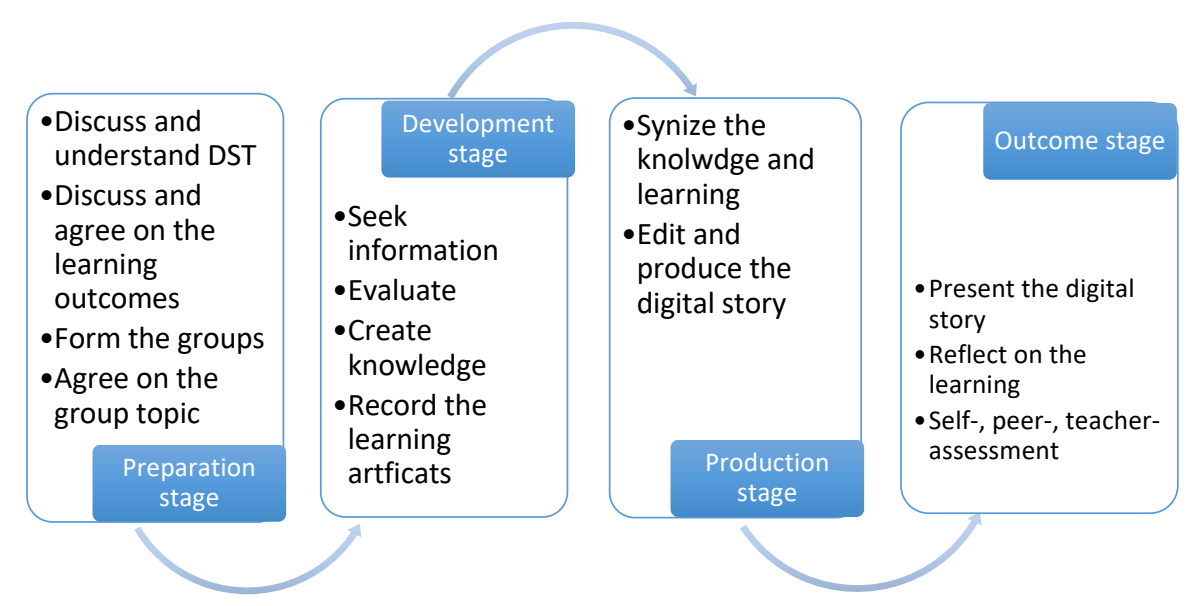

Figure 1. The process and steps of DST as a pedagogical method.

According to Niemi et al. (2014), learning with DST is seen as a socially and culturally related process that takes place in the interaction between a learner and material tools, psychological tools, or other human beings (Vygotsky, 1978). Learners play a central role in exploring and building knowledge by using tools available in the digital learning environment. When planning, and making digital stories collaboratively, students can become aware of their own knowledge and 
experiences and reflect on and share these experiences with others. Watching other students' stories can also create new perspectives on topics and promote the understanding of a certain phenomenon (Niemi et al., 2014).

DST pedagogy draws from learner-centered approaches that aim to enable student learning through the use of connective technologies, digital mobile devices and language toward the production of meaningful stories (McGee, 2015). The aim of this educational method (McGee, 2015) is to give pupils a chance to tell their own stories about the topic under discussion. The method highlights a do-it-yourself attitude, participatory practice, and constructive creative elements in creating the story; increases engagement on the topic; is collaborative; encourages active participation; blurs the roles of the learner and the instructor; and encourages shared learning and creativity (Lambert, 2013; McGee, 2015; Niemi et al., 2014; Sadik, 2008; Shelby-Caffey, Úbéda, \& Jenkins, 2014; Sukovic, 2014; Woodhouse, 2008).

When designing, shooting and evaluating the videos, the students acquire knowledge that is related to their video topics. Glynda Hull's extensive experience of using digital storytelling among young people from different cultural contexts and in danger of dropping out provides evidence that sharing experiences through student-driven videos is a highly empowering tool (Hull \& Katz, 2006; Hull, Kenney, Marple, \& Forsman-Schneider, 2006; Hull et al., 2009). In addition, Robin (2008) suggested that digital storytelling takes advantage of the creative potential of modern communication technologies. In this way, students are encouraged to become creators, producers and discussants, rather than simply passive audience members.

Table 1 presents the types of stories that emerged from the analysis of content and mode of production in earlier studies (Vivitsou et al., 2016) in relation to subjectbased or integrated teaching approaches. It should be noted, however, that the categories are neither mutually exclusive nor compact.

\begin{tabular}{lll}
\hline & Single stories & Multiple event stories \\
\hline $\begin{array}{l}\text { Subject-based digital } \\
\text { stories }\end{array}$ & Multiple-phenomenon based stories \\
phenomenon & & \\
& - Chemical reaction & $\begin{array}{l}\text { Science subjects: water, motion, } \\
\text { air }\end{array}$ \\
& $\begin{array}{l}\text { Humanistic subjects: historical } \\
\text { events, biographies, language } \\
\text { topics }\end{array}$ \\
& \\
& \\
&
\end{tabular}




\begin{tabular}{lll}
\hline $\begin{array}{l}\text { Interdisciplinary } \\
\text { digital stories }\end{array}$ & $\begin{array}{l}\text { Instances of an } \\
\text { interdisciplinary } \\
\text { phenomenon }\end{array}$ & Theme-based stories \\
& $\begin{array}{ll}\text { - One event in a forest } \\
\text { on a field trip }\end{array}$ & - Recycling \\
& - Myths \\
& - Animal testing \\
$\begin{array}{l}\text { Student-initiated } \\
\text { stories }\end{array}$ & $\begin{array}{l}\text { Introducing myself and } \\
\text { my class to peers }\end{array}$ & Instances from everyday life \\
& & - Hobbies \\
& & - My friends \\
& & - Cthical issues \\
&
\end{tabular}

Table 1. Types of Digital stories (Vivitsou et al., 2016)

As the table shows, stories could be focused on a single event or on longer descriptions as a series of events. Students also created both subject specific and interdisciplinary stories. The latter often featured a more structured narrative by recounting multiple events. In their stories, for example, students used 'real-life' characters as a peer or as a narrator, whilst in others they used fictional characters to pull the narrative together and convey the message.

In DST students are responsible for their own learning process and learning outcomes with the support from teachers. The role of teachers also changes in this pedagogical approach. The teachers are no longer in the center of the classroom. The students are in the center of the stage, and the teachers are at the side. The classroom is filled with students' voice, not with teachers' speeches. However, it is not only the students who take up a more active role in the pedagogical process. The teachers also need to adapt their teaching practices in order to successfully meet the requirements of the new situation. Therefore, the teachers' role changes as well.

\section{Toward Global Sharing Pedagogy}

The Finnish research project Finnable 2020 has drafted a model of the Global Sharing Pedagogy (GSP) for promoting $21^{\text {st }}$ century skills in schools with digital storytelling (Niemi et al., 2014, Niemi \& Multisilta, 2016). The aim has been to connect megatrends of changes in learning concepts, knowledge creation, and working life with teaching and learning. The GSP is based on socio-cultural theories where learning is viewed as a result of dialogical interactions between people, substances, and artifacts (Pea, 2004; Cole \& Cigagas, 2010; Säljö, 2012; Hakkarainen, Paavola, Kangas, \& Seitamaa-Hakkarainen, 2013). The primary 
objective is to strengthen student engagement in learning and mediate students as they become active learners and knowledge creators in changes they are facing already, and will increasingly face in their future. However, engagement is not viewed only as an end. It is also a means for further learning. It is regarded as a motivational component that consists of the emotional states of students, such as the joy and fun experienced in learning, as well as qualities that are typical of selfregulated learning. It includes commitment to learning tasks, and a willingness to make efforts to achieve an objective (Pintrich, 2000; Pintrich \& McKeachie, 2000).

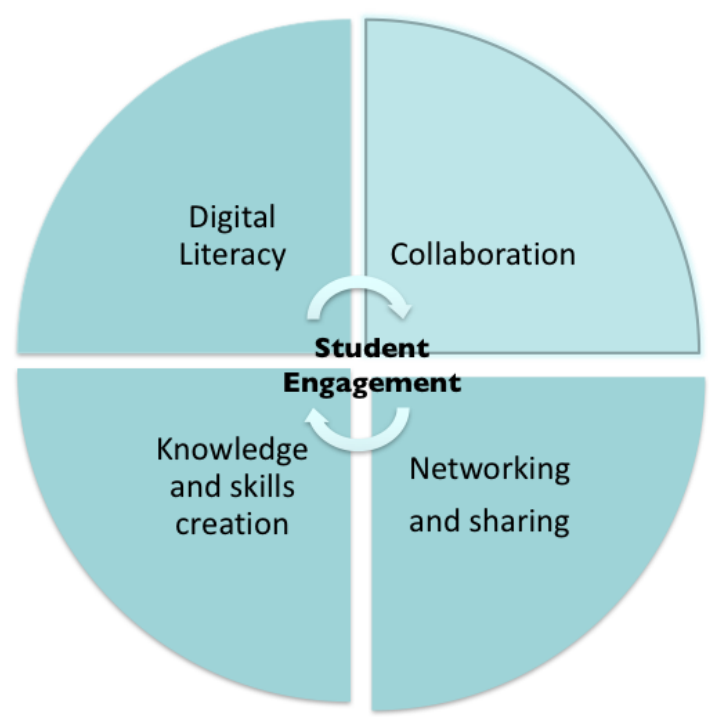

Figure 2. The components of Global Sharing Pedagogy

Learner-driven knowledge and skills creation is an objective that provides learners with symbolic tools for the development of active learning methods and metacognitive skills. This is a dynamic process in which learners, guided by reflection and metacognition, manage their thinking and learning resources. Learners require strategic skills to manage their own learning and create new knowledge, both individually and collaboratively (Pintrich \& McKeachie 2000; Nevgi, Virtanen, \& Niemi, 2006). Schools and teachers should encourage students to engage in this type of independent learning (Niemi, 2002; Scardamalia, 2002; Scardamalia \& Bereiter, 2003). Learning affects students cognitively, emotionally, socially, and morally, and the more independent and self-regulating students are, the more they must also be aware of, and employ, ethics and values. Mediation 
toward student-driven knowledge creation consists of different kinds of symbolic tools, such as critical thinking, creativity, argumentation, "learning to learn" skills, and ethics and values.

Collaboration is a social objective that allows or requires students to work together (Hull et al., 2009; Pea \& Lindgren, 2008; Rogoff, 1990; Wells 1999). It ensures that they can learn and work in the global world in the future; they must develop the following competencies beyond the purely "cognitive": social skills, cultural literacy and understanding, help-seeking, and help-giving strategies.

Networking is also a social objective that uses synergy of expertise of other people and also provides tools for intercultural learning (Starke-Meyerring, Duin, \& Palvetzian, 2007; Starke-Meyerring \& Wilson, 2008). In distributed cognitions and interaction with different artifacts, people introduce remarkable value that enhances their learning and competencies. These processes are mutually constitutive. All learners are also contributors. Thus, networking means sharing alearning from others, as well as sharing ideas and experiences.

Digital media competencies and literacies is an objective that enriches learning through new technology environments, but it can also consist of social and symbolic mediators though different kinds of digital environments (Säljö, 2012). In technological environments, learners are both content producers and consumers. As such, they need the skills to study and work in digital environments. They must also critically assess and validate the knowledge they find and create; they must be accountable to the norms of discourse and argumentation established by the adult communities of practice in each discipline. They also require skills in the creation and discussion of social media, and in promoting ethical behavior in these media environments. Mediation of digital media competencies and literacy consists of the following skills that schools should provide to students: content creation, with critical content interpretations and validation, and social media skills that are part of digital environments.

\section{THREE CASE STUDIES OF LEARNING WITH DST}

\section{Digital stories across countries}

In a related study, we introduce how digital storytelling can create virtual learning environments when it is used for learning $21^{\text {st }}$-century skills and competencies needed in students' future working life (Niemi et al., 2014; Niemi \& Multisilta, 2016). The study describes how students $(n=319)$ in three countries and their teachers $(n=28)$ value digital storytelling and what they think students have 
learned. Their experiences are analyzed using a theoretical conceptualization of the global sharing pedagogy that sets categories of processes or tools as objectives: 1) learner-driven knowledge and skills creation, 2) collaboration, 3) networking, and 4) digital literacy. Analyses have been quantitative and qualitative. The study describes students' experiences when they created their digital stories and how they engaged in learning.

Data was collected between September and November 2012. The participating students were in elementary, lower, and upper secondary schools in three countries: Finland, the USA (California) and Greece. The total number of students-participants was 319 , with a balanced gender distribution of 159 girls and 160 boys. There were 28 teachers. Most students were between 10 and 14 years old. The students created over 1000 videos altogether. Most of them were between 2 and 4 minutes in length. Schools and teachers had the freedom to choose how they wanted to use DST in their teaching.

Stories included language learning, physics, chemistry, biology, and history. In some classes, the topics were multidisciplinary. They could combine, for example, traffic education, language learning, and art in the topic. Video stories could also work as educational videos, where students taught other students to do something. This happened in one second-grade class; students made video stories in their teddy bear project, where they taught other students how to make different handicrafts.

The major findings are that students enjoyed creating their stories, and they were very engaged in their work. They learned many $21^{\text {st }}$-century skills when creating their digital stories. The findings strongly support that learning with DST method has powerful effect on students' motivation and enthusiasm, including both fun and commitment to hard work. This study shows that students enjoy creating digital stories, and they are engaged in school work. However, they need more skills in collaboration, opportunities for networking, and teachers' guidance in knowledge creation and digital competencies.

\section{Video Inquiry Project: STEM Learning and Teaching with DST}

The second project was established in 2013 and involved the collaboration among Stanford University, Helsinki University, University of Lapland, and Pepperdine University (Penttilä et al., 2016). The 'Video Inquiry Project: STEM Learning and Teaching with Mobile Video Inquiries and Communities' (2013-2015) aimed to seek innovative tools and research findings to support new pedagogical models that simultaneously foster learners' and teachers' interests in and joint attention to the power of science and mathematics in explaining phenomena 'in the everyday world'. 
The students created short video stories collaboratively in this project too. Having designed, captured and edited the stories, students shared their work with peers online (Vivitsou et al., 2017; Penttilä et al.. 2016). One topic was: motion. The learning objectives focused mainly on the ability to identify and classify different types of motion, such as linear, curvilinear, and constant, and also to qualitatively understand the concepts of velocity, acceleration, and force.

Based on the digital stories, students' epistemic thinking about the phenomenon of motion widened during the learning period from everyday-like to more scientific. For instance, in their orientation videos students often equated motion to the physical activity of human beings. Thus, they filmed each other while doing different kinds of exercises (e.g., walking, jumping, doing cartwheels etc.). Eventually, the videos that only a few had captured from inanimate objects (e.g., a helicopter flying in the sky) ended up being of importance in helping the students to see motion from a broader perspective, implying an ability to observe motion everywhere in their surroundings as one of the students stated in the final interview:

'I'd say that motion can be observed just about anywhere'.

This broader understanding also included definitions of different kinds of motion phenomena. For example, in their digital stories the students were able to define the motion of a rollercoaster ride as curvilinear, or of a bus leaving from a bus stop as an accelerating motion.

The second topic was: air. During a visit to a science center where students were exploring the theme of air, was an exhibition of a hot air balloon. In the exhibition, the balloon was rising and falling depending on air temperature, while the temperature was observable from a thermometer placed close to the landing spot of the balloon. While observing this process and listening to the guide explaining its causes and effects, students familiarized with the mechanisms of how a hot air balloon works and used this information in their stories to highlight the key points such as 'air requires space' and 'warm air rises and expands'. In this sense, students also considered their digital stories as image-based notes of their observations and found them useful in enhancing their memory.

Working with teachers by employing design-based research methodology, they established a web-based community platform for uploading short-form STEMrelated videos and associated inquiry questions developed by participating learners and teachers, and develop scaffolding and social media functions for making reflective connections from these video resources to curriculum topics and classroom activities. 
The immense quantity of video resulting from digital video cameras everywhere was making video ubiquitous as a cultural medium and in principle, as a scientific medium for STEM educational purposes. This project conducted design-based research and development to establish a broadly scalable approach for students and teachers to capture standard and video recordings of events and phenomena that spark questions for them that can serve as seeds for inquiries in the STEM disciplines.

\section{Learning math and $21^{\text {st }}$ century competences with DST}

In 2016, University of Helsinki and Beijing Normal University initated a joint project focused on how students can learn $21^{\text {st }}$ century competences in math learning. The project was part of the Future School 2030 project led by the Advanced Innovation Center for Future Education (AICFE) at Beijing Normal University.

The theme focused on calculating the area size of 3 different geometry shapes. However, the pedagogical course design was also multi-disciplinary. Math learning with Digital Storytelling (DST) required the students to seek and learn various knowledge and skills. In order to produce the digital story in math learning, the students also needed to learn language, visual arts, music, and computer software. This required collaboration among teachers and principals, parents and friends. In this way, a collaborative learning community was created.

When starting the project, the teachers explained to the students what the DST method and discussed with students what the main elements, processes, and learning outcomes in doing DST are. The participating students were $4^{\text {th }}$ and $5^{\text {th }}$ graders, 10-11 year-old young adolescents in primary school in Beijing in China and in Helsinki in Finland. Four classes from China were involved in this research, a total of 135 students. In Finland, there were two calsses with a total of 49 students.

Learning mathematics involves developing abstract thinking, in addition to handling a series of complex mathematical concepts. In many schools, both in Finland and China, teaching math remains teacher-centered and usually of a 'stageon-the-stage' type. The project was interested to look into how a student-centered, collaboration-oriented approach allows for deeper and wider student engagement. The data was collected through pre-questionnaires, daily questionnaires, postquestionnaires, observations, and interviews with students and teachers.

The analysis of the students' questionnaire evaluation and the students' and teachers' interviews indicates that DST can promote learning math in schools and well as $21^{\text {st }}$ century skills. The skills that were chosen to be measured were based 
on the components of Global Sharing Pedagogy: Knowledge creation, Collaboration, Networking with Knowledge sharing and Digital competences. Figure 2 illustrates how DST has promoted students' learning successfully in this project. It also describes that students' engagement has been very high. They have veen very motivated to work hard and they have enjoyed learning (Niemi, et al., 2018). 
Figure 3. Students' self-evaluations about their learning in DST project in Finland and China.

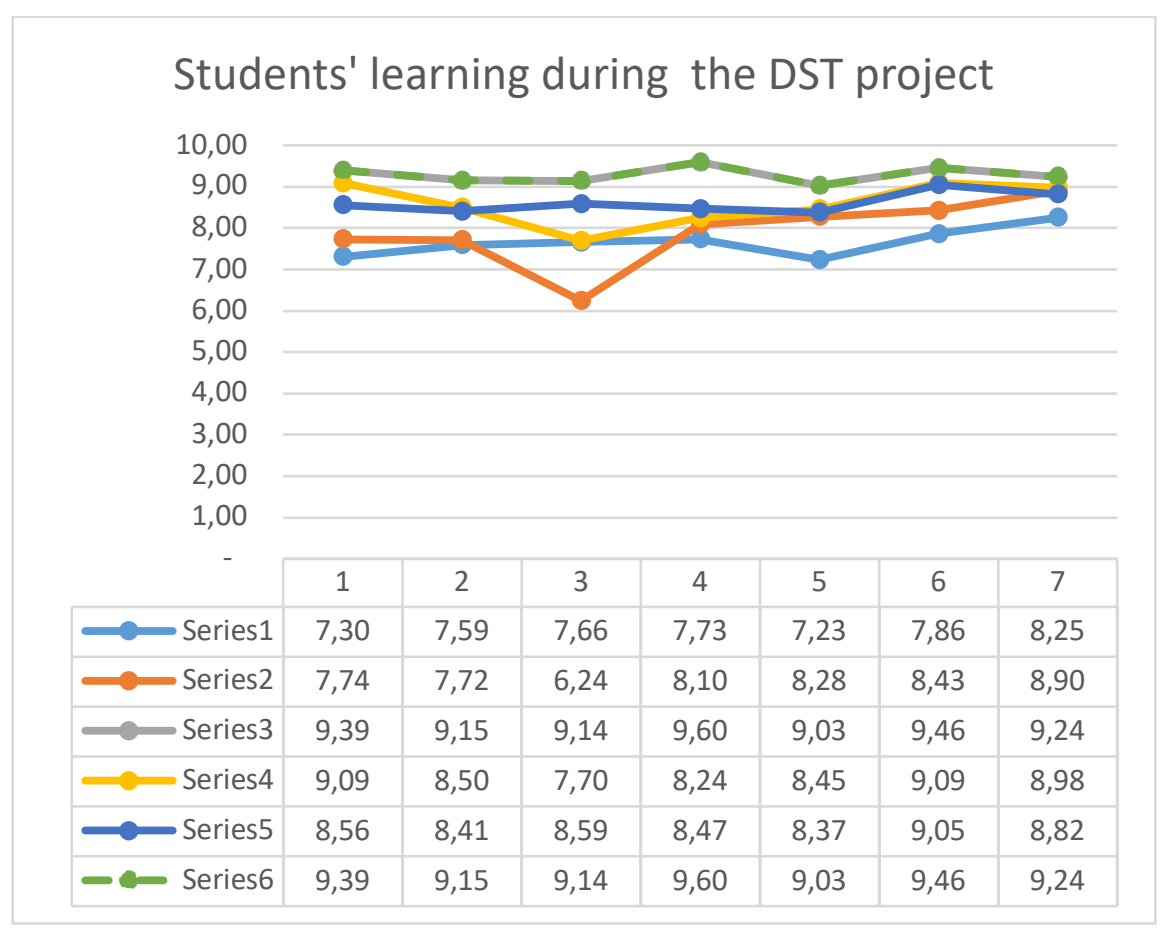

Finnish classrooms: Series 1- 2; Chinese classrooms: series 3-6.

I learned the following things during the storytelling project. Evaluate according to your own opinion how accurately the following statements describe you. The scale is: ( Not al all) $1 . . .10$ (very much) (Niemi et al., 2018)

1. I learned new knowledge about math

2. I learned how math relates to everyday life

3. I learned new skills such as recording and editing videos, finding new information from books or the Internet etc.

4. I learned how to work in a group with my classmates

5. I gained new ideas from my peers

6. In my opinion, it was fun to do tasks that relate to digital storytelling

7. I worked hard during the lesson/phase of work

The main conclusions of this research project are:

- Learning math with DST can increase students' motivation and engagement; 
- DST pedagogical method can support students' learning towards $21^{\text {st }}$ century skills;

- Students enjoyed this learning method,

- Students need more support in technical issues of video creation

\section{Discussions and conclusions}

\section{Learning $21^{\text {st }}$ century skills through DST}

Bernard (2008) stated that students can get benefits when they are given the task of creating their own digital stories. This creative work provides students with a strong foundation in what many educators have begun calling $21^{\text {st }}$ Century Skills. Students can develop enhanced communication skills as they learn to conduct research a topic, ask questions, organize their ideas, express opinions, and construct meaningful narratives. In Blas and Paolini's (2013) large-scale digital storytelling initiative, students can increase their knowledge through interacting with external institutions, experts, instructors and peers, raise the learning interest and foster the communication skills and media literacy. DST fosters collaboration and coconstruction of meaning.

The key elements of the DST pedagogical method is collaborative work during the whole project. Students work in small groups to search and analysis information, and to create the knowledge and digital story together. There are lots of interactions among students themselves and with teachers while making the digital story. The students gradually learn how to express themselves, how to discuss with others, how to negotiate, how to influence others, and how to contribute in team work. In our students' interviews, almost every student highlighted the group work collaboration, and how they have achieved agreement when there are different opinions and ideas. Based on our three case studies, students' communication skills and collaboration skills have been greatly developed while conducting DST learning.

Cultural competence, interaction, and expression are essential parts of DST because everything happens in groups, and many themes of the video products can focus on wide societal, cultural, and ethical themes (e.g., recycling, homelessness, and animal testing). The work of the DST projects can also be related to many themes that promote managing daily life and taking care of oneself and others.

Because students learn recording, editing, mixing, and applying various information sources, they also learn multi-literacy in the context of multimodality, where digital 
and traditional literacies are connected and integrated with ICT-competence. DST connects formal and informal learning settings by crossing borders in knowledge creation. Traditionally, a story needs a beginning, a middle and an end to be considered a story. Nowadays, however, more avant-garde views question the triple feature and allow for less fixed definitions. Stories can recount a single event or an array of events. Given this, and taking into consideration that telling a story is not attached to one mode of expression (e.g., oral or written speech only), we can say that the use of the term is rather metaphorical nowadays. Although 'storytelling' used to be associated with oral expression, it now refers to a variety of modes of fixation and inscription (e.g., writing, acting out a role, filming etc.).

According to Stewart and Gachago's (2016) study, DST can be used to facilitate an engagement across border s/continents with differently positioned students. Also, there is evidence suggesting that the method encourages active participation as well as shared learning and creativity (Lambert, 2013; McGee, 2015; Niemi et al., 2014; Sadik, 2008; Shelby-Caffey, Úbéda, \& Jenkins, 2014; Sukovic, 2014; Woodhouse, 2008). Digital storytelling, therefore, is one way to increase engagement in school learning (Niemi \& Multisilta 2016). In storytelling projects students work collaboratively in technology-rich environments by sharing their ideas. They inquire and create new knowledge by learning from each other and assess their learning processes and products.

There are also some challenges in doing DST. One of the main challenges is time. Students-centered learning with DST pedagogical method may take longer time than the normal lecture hours in the beginning when teachers and students are not familiar with this method. However, we need to remember that students are not only learning content knowledge, but also skills and competences. Developing skills and competences needs time and continuous practice. Therefore, schools and teachers need to prepare enough time in the beginning when starting using the DST method. Once teachers and students become familiar with the method, it will be more and more easy and less time consuming. Therefore, the curriculum must be flexible. And over time the students will gain more skills and competences which they need now and specially in the future with continuous practice and development.

Another issue that requires further attention is how to evaluate student-generated digital stories. In the three cases discussed above, the evaluation of digital storytelling activities served both research and pedagogical purposes. As mentioned previously, questionnaires, field observations and interviews were used for research. In addition, for pedagogy, students reflected on the process and exchanged views in groups. Students also gave feed back to their peers' videos. This type of self- and peer-evaluation is consistent with learner-centered approaches that make room for students to develop awareness of the process and grow into more autonomous learners by, for example, setting objectives, revise the learning plan and regulate their progress. In this way, evaluation can contribute to the improvement of operational processes and the quality of learning outcomes that related to $21^{\text {st }}$ century competences (Harju \& Niemi 2017). Self-evaluation, peer 
evaluation, and supportive formative evaluation are important methods targeting a holistic approach and a deeper understanding of student development, along with a broader view into what the learning progress looks like.

In all cases, the common feature was that students would need more criteria how they can evaluate their own and peers' products. They need more awareness about the aims and what constitute quality criteria, e.g., how a good story takes audience into consideration, how contents are introduced and argued, and how different learners participated in collaboration. Criteria could allow young students form a concrete understanding of related constructs (e.g., the narrative and associated meanings, relevant concepts and so on) and, thus, develop a meta-awareness of telling and sharing digital stories.

In digital storytelling, the knowledge building factor relates to subject-matter and how well the student grasps the object (or content) of study. For instance, if the content is about geometrical shapes (e.g., triangles), the digital story should present relevant thematic dimensions, concepts and terms, and organize and present them in a clear and coherent manner. In this way, the narrative structure of the story will make sense in relation to the formal content. In order to support students' learning trhoug evaluation describtive rubrics could help to get a general idea of the digital storytelling and, thus, more accurate understanding of the complex, multidimensional digital story production process.

To summarize, Digital Storytelling (DST) is a very powerful and effective learning and teaching method That:

- Supports students' learning $21^{\text {st }}$ skill, especially collaboration, communication, creativity, critical thinking, ICT and multi-literacy skills which are extremely important in everyday life.

- Increases students' motivation, engagement and agency in learning, and it builds confidence in students. The confidence building and success feeling are extremely important in student's optimism in future learning. Failure is also great learning opportunity. It is the opportunity to develop students' growth mindset and to develop students' perseveres in future learning situation and in their life situations. Learning from mistakes can develop students' encourage and mindset.

- Modifies the roles of teacher and students. The students are in the center of the learning process and have more agency in their activities. They are knowledge creators, and they are responsible for their own learning and competences building. Teachers are facilitators, coaches and act to scaffold learning.

- Impacts assessment in different ways: for encouragement and further development with constructive feedback and student self-assessment, peer assessment and teacher assessment. The assessment is for learning, as learning and of the learning with different assessment methods. 
- Enables schools to become learning communities. Principals, teachers, students, parents, friends, companies, societies are all in this learning community to support students' learning and competences development.

- Creates some challenges in using the methods. But these are not obstacles, As they can be turned to opportunities to achieve great learning outcomes with time and hard work.

The ultimate goal is to create a meaningful and joyful learning community at school where the students not only learn subject knowledge, but, even more importantly, develop the skills and competences necessary for their everyday life and their future work. DST is effective student-centered pedagogical method which can develop students' $21^{\text {st }}$ century skills, agency with increase engagement. It can also be combined with other learning methods to achieve desired learning outcomes.

\section{References}

Autor, D. (2010). The Polarization of Job Opportunities in the US Labor Market. Center for American Progress and The Hamilton Project, April 2010.

Bellanca, J. \& Brandt, R. (2010). 21st century skills: Rethinking how students learn. Bloomington, IN: Solution Tree.

Bernard R. Robin. (2008). Digital storytelling: a powerful technology tool for the 21 st century classroom. Theory Into Practice, 47(3), 220-228.

Binkley, M., Erstad, O., Herman, J., Raizen, S., Ripley, M., Miller-Ricci, M., \& Rumble, M. (2012). Defining twenty-first century skills. In P. Griffin, B. McGaw, \& E. Care (Eds.), Assessment and teaching of 21st century skills (pp. 17-66). Dordrecht: Springer.

Cole, M. (1991). Conclusion. In L. B. Resnick, J. M. Levine, \& S. D. Teasley (Eds.), Perspectives on socially shared-cognition (pp. 398-417). Washington, DC: American Psychological Association.

Cole, M., \& Cigagas, X. E. (2010). Culture and Cognition. In M. H. Bornstein (Ed.), Handbook of Cultural Developmental Science (pp. 127-142). New York, NY: Psychology Press.

Davies, A. Fidler, D., \& Gorbis. D. (2011). Future Work Skills 2020. Palo Alto, CA: Institute for the Future for University of Phoenix Research Institute. Retrieved Feb. 19, 2014 http://www.iftf.org/uploads/media/SR-1382A UPRI future work skills sm.pdf

Euopean Union (2006). Recommendation of the European Parliament and of the Council of 18 December 2006 on key competences for lifelong learning (2006/962/EC). Official Journal of the European Union, 30.12.2006, L 394/10. 
Griffin, P. (2013, August). The assessment and teaching of 21st century skills (ATCS21STM). Presentation at TERA \& PROMS Conference, Taiwan.

Griffin, P., McGaw, B., \& Care, E. (2012). The changing role of education and schools. In P. Griffin, B. McGaw, \& E. Care (Eds.), Assessment and teaching of 21st century skills (pp. 116). Dordrecht: Springer Science+Business Media BV. doi:10.1007/978-94-007-2324-5_2.

Griffin, P., McGaw, B., \& Care, E. (Eds.). (2013). Assessment and teaching of 21st century skills (pp. 17-66). Dordrecht, Germany: Springer Science+Business Media B.V. doi:10.1007/97894-007-2324-5_2

Hakkarainen, K., Paavola, S., Kangas, K., \& Seitamaa-Hakkarainen, P. (2013). Sociocultural Perspectives on Collaborative Learning: Towards Collaborative Knowledge Creation. In C. E. Hmelo-Silver, A. M. O’Donnell, C. Chan, \& C. A. Chinn (Eds.), The International Handbook of Collaborative Learning (pp. 57-73). New York, Routledge.

Harju, V. \& Niemi, H. (2017) Transversal competencies in Finnish basic education (in Chinese). Assessment \& Evaluation in Higher Education.

Hull, G., \& Katz, M. L. (2006). Crafting an agentive self: Case studies in Digital Storytelling. Research in the Teaching of English, 41, 43-81.

Hull, L, Zacher, J \& Hibbert, L (2009). Youth, risk, and equity in a global world, Review of Research in Education, 33(1), 117-159.

Jenkins, H., Purushotma, R., Weigel, M., Clinton, K., \& Robinson, A. J. (2009). Confronting the challenges of participatory culture: Media education for the twenty-first century. Chicago, IL: The MacArthur Foundation and London: The MIT Press.

Jones, B., Valdez, G., Nowakowski, J., \& Rasmussen, C. (1994). Designing Learning and Technology for Educational Reform. Oak Brook, IL: North Central Regional Educational Laboratory.

Kearney, M. (2009). Towards a Learning Design for Student-Generated Digital Storytelling (DST) . Article Presented in Conference: The Future of Learning Design Conference. New South Wales, Australia: University of Wollongong. http://ro.uow.edu.au/gi/viewcon$\underline{\text { tent.cgi? } \text { article }=1003 \& \text { context }=\text { fld }}$

Lambert, J. (2013). Digital Storytelling (DST) : Capturing lives, creating community. New York, NY: Routledge.

McGee, P. (2015). The instructional value of Digital Storytelling (DST) : Higher education, professional, and adult learning settings. New York, NY: Routledge.

Multisilta, J. (2012). Designing learning ecosystems for mobile social media. In A. D. Olofsson \& J. O. Lindberg (Eds.), Informed design of educational technologies in higher education (pp. 270-291). Hershey, PA: IGI Global.

Nevgi, A., Virtanen, P., \& Niemi, H. (2006). Supporting students to develop collaborative learning skills in technology-based environments. British Journal of Educational Technology, 37, 937-947. 
Niemi, H. (2009). Why from teaching to learning. European Educational Research Journal, 8 (1), $1-17$.

Niemi, H. (2002). Active learning - A cultural change needed in teacher education and in schools. Teaching and Teacher Education, 18, 763-780.

Niemi, H. (2003). Competence building in life-wide learning: Innovation, competence building and social cohesion in Europe, (pp. 219-239). Cheltenham: Edward Elgar.

Niemi, H, Harju, V, Vivitsou, M, Viitanen, K, Multisilta, J, \& Kuokkanen, A. (2014). Digital Storytelling for 21 st-century skills in virtual learning environments, Creative Education, 5(9), $657-671$.

Niemi, H., \& Multisilta, J. (2014). Towards Global Sharing Pedagogy. In H. Niemi, J. Multisilta, \& E. Löfström (Eds.), Crossing Boundaries for Learning_Through Technology and Human Efforts. Helsinki: Cicero Learning, University of Helsinki.

Niemi, H \& Multisilta, J (2016). Digital Storytelling promoting twenty-first century skills and student engagement, Technology, Pedagogy and Education, DOI 101080/1475939X20151074610

Niemi, H., Niu, J., Vivitsou, M., \& Li, B., (submitted June 2018). Digital storytelling promoting 21" century competences, math literacy and high engagement, Contemporary Educational Technology

Niemi, H., Kynäslahti, H., \& Vahtivuori-Hänninen, S. (2013). Towards ICT in everyday life in Finnish schools: Seeking conditions for good practices. Learning, Media and Technology, 38, 57-71. doi:10.1080/17439884.2011.651473.

Nonaka, I., \& Konno, N. (1998). The Concept of 'Ba': building a foundation for knowledge creation. California Management Review, 40(3), 40-54.

Nonaka, I., \& Takeuchi, H. (1995). The knowledge-creating company: How Japanese companies create the dynamics of innovation. New York: Oxford University Press.

Nonaka, I., \& Toyama, R. (2003). The knowledge-creating theory revisited: Knowledge creation as a synthesizing process. Knowledge Management Research \& Practice, 1, 2-10.

Passey, D., \& Multisilta J. (Eds.). (2014). Special Issue: Special Section on Intergenerational Learning and Digital Technologies and Special Section on Mobile and Panoramic Video in Education. Education and Information Technologies, 19(3).

Pea, R. D. (2004). The social and technological dimensions of scaffolding and related theoretical concepts for learning, education, and human activity, The Journal of the Learning Sciences, 13(3), pp. 423-451.

Pea, R, \& Lindgren, R (2008). Collaboration design patterns in uses of a video platform for research and education. IEEE Transactions on Learning Technologies, 1(4), pp. 235-247.

Penttilä, J., Kallunki, V., Niemi, H. M. \& Multisilta, J. (2016). A Structured Inquiry into a Digital Story: Primary School Students Report the Making of a Superball. International Journal of Mobile and Blended Learning, 8(3), pp. 19-34. 
Pintrich, P. R., \& Ruohotie, P. (Eds.). (2000). Conative constructions and self-regulated learning. Hämeenlinna, Finland: RCVE.

Pintrich, P. R., \& McKeachie, W. J. (2000). A Framework for Conceptualizing Student Motivation and Self-Regulated Learning in the College Classroom. In P. R. Pintrich, \& P. Ruohotie (Eds.), Conative Constructions and Self-Regulated Learning (pp. 31-50). Hämeenlinna: RCVE.

Robin, B. (2008). Digital Storytelling (DST) : A powerful technology tool for the 21 st century classroom, Theory into practice, 47, 220-228.

Rogoff, B. (1990). Apprenticeship in thinking: Cognitive development in social context. New York: Oxford University Press.

Sadik, A. (2008). Digital Storytelling (DST) : A meaningful technology-integrated approach for engaged student learning. Educational Technology Research \& Development, 56, 487-506.

Salomon, G. (1993). No distribution without individual's cognition: A dynamic interactional view. In G. Salomon (Ed.), Distributed cognitions: Psychological and educational considerations (pp. 111-138). Cambridge: Cambridge University Press.

Shelby-Caffey, C., Úbéda, E., \& Jenkins, B. (2014). Digital Storytelling revisited. The Reading Teacher, 68(3), 191-199.

Scardamalia, M. (2002). Collective cognitive responsibility for the advancement of knowledge. In B. Smith (Ed.), Liberal education in a knowledge society (pp. 67-98). Chicago, IL: Open Court.

Scardamalia, M., \& Bereiter, C. (2003). Knowledge building. In J. W. Guthrie (Ed.), Encyclopedia of education (2nd ed., pp. 1370-1373). New York, NY: Macmillan Reference.

Schleicher, A. (2012). Preparing Teachers and School Leaders for the 21st Century-Ministers and Union Leaders Meet on How to Turn Visions into Reality. https://community.oecd.org/community/educationtoday/blog/2012/03/17/preparing-teachers-and-schoolleaders-for-the-21st-century-ministers-and-union-leaders-meet-on-how-to-turn-visions-intoreality.

Starke-Meyerring, D, Duin, A H, \& Palvetzian, T (2007). Global partnerships: Positioning technical communication programs in the context of globalization, Technical Communication Quarterly, 16(2), 139-174.

Starke-Meyerring, D, \& Wilson, M (Eds) (2008). Designing globally networked learning environments: Visionary partnerships, policies, and pedagogies. Rotterdam: Sense Publishers

Stewart, K. and Gachago, D. (2016), Being human today: A digital storytelling pedagogy for transcontinental border crossing. Br J Educ Technol, 47: 528-542.

Sukovic, S (2014). iTell: Transliteracy and Digital Storytelling. Australian Academic \& Research Libraries, 45(3), 205-229.

Säljö, R. (2010). Digital tools and challenges to institutional traditions of learning: technologies, social memory and the performative nature of learning. Journal of Computer Assisted Learning, 26(1), pp. 53-64. 
Säljö, R. (2012). Schooling and spaces for learning: Cultural dynamics and student participation and agency In E Hjörne, G van der Aalsvoort, \& G Abreu (Eds), Learning, social interaction and diversity - Exploring school practices (pp 9-14) Rotterdam: Sense.

Taylor, L., \& Parsons, J. (2011). Improving student engagement. Current Issues in Education, 14(1), 1-33

Vivitsou, M. Kallunki, V., Niemi, H., Penttilä, J. \& Harju, V. (2016). Student-driven knowledge creation through Digital Storytelling. In Niemi, H. \& Jia, J. (Eds.) New Ways to Teach and Learn in China and Finland: Crossing Boundaries with Technology. Frankfurt: Peter Lang, pp. $35-54$.

Miao, R. (forthcoming). Teachers' practices to support student work in Digital Storytelling: A study on Finnish and Chinese school teachers' experiences.

Vygotsky, L. (1978). Mind in society. Cambridge, MA: The MIT Press.

Wells, G. (1999). Dialogic inquiry: Towards a sociocultural practice and theory of education. Cambridge: Cambridge University Press.

Yang, Y. T. C., \& Wu, W. C. I. (2012). Digital Storytelling (DST) for Enhancing Student Academic Achievement, Critical Thinking, and Learning Motivation: A Year-Long Experimental Study. Computers \& Education, 59, 339-352. http://dx.doi.org/10.1016/j.compedu.2011.12.012

Woodhouse, J. (2008). Storytelling: A telling approach in healthcare education. Paper presented at the Narrative Practitioner Conference, Wrexham, England. 


\section{Authors' Bio:}

\section{Hannele Niemi}

$\mathrm{PhD}$, Professor, UNESCO Chair on Educational Ecosystems for Equity

and Quality of LearningFaculty of Educational Sciences,

University of Helsinki

E-mail: hannele.niemi@helsinki.fi

Hannele Niemi is Professor, Research Director at the University of Helsinki and she has nominated as UNESCO Chair on Educational Ecosystems for Equity and Quality of Learning 2018-2021. She is the Chair of The University Board at the University of Lapland. She is also the Chair of the SinoFinnish Joint Learning Innovation Institute (JoLii) that includes 9 Finnish universities, working in cooperation with Beijing Normal University and many other universities in China. Her experience at the University of Helsinki also includes her roles as the Vice Rector for Academic Affairs (20032009), the Professor of Education (1998-2016), the Dean of the Faculty of Education (2001-2003). She also served as a Visiting Professor at Michigan State University (1989) and as a short Visiting Scholar at Stanford University (2010, 2013, and 2015).

Shuanghong Jenny Niu

D.Sc., Postdoctoral Researcher

Faculty of Educational Sciences, University of Helsinki

E-mail: jenny.niu@helsinki.fi

Shuanghong Jenny Niu is working as a postdoctoral researcher in Faculty of Educational Sciences at University of Helsinki. Shuanghong Jenny Niu obtained her Master Degree and D.Sc. from Aalto University in Finland. She is dedicated in the research fields of school leadership and management; teachers' education and training; learning and teaching methods; and the development of 21 st century skills. She provides teachings for school principals and teachers with the courses of School leadership and management, Phenomenon-based learning, and Digital storytelling teaching and learning method. She also co-translated several books from English to Chinese, such as Timothy Walker's book of Teach Like Finland, Ben Furman's books of Change Through Cooperation and The Twin Star. She has over 20 years rich working experience in international companies and several universities. 


\section{Baopin LI}

Ph.D, Beijing Normal University

E-mail: libp@bnu.edu.cn

Baoping LI is currently a researcher at the Advanced Innovation Center of Future Education at Beijing Normal University, China. She obtained her $\mathrm{Ph}$.D. in Education from Beijing Normal University, China in 2009. Her research interests include the teachers'and students' perceptions of technology-rich learning environments, designing innovative learning activities for one student learn with one smart terminal learning environment, and evaluation of students' innovation ability.

\section{Marianna Vivitsou}

$\mathrm{Ph} . \mathrm{D}$, post-doctoral researcher, University of Helsinki

E-mail: marianna.vivitsou@gmail.com

Marianna Vivitsou, $\mathrm{PhD}$, is post-doctoral researcher at the University of Helsinki in the field of social media, web-based technologies and digital storytelling. Her work looks into digital storytelling as a metaphor of the 21 st century with pedagogical and wider socio-technical dimensions and implications. 